НАВЧАННЯ МАЙБУТНІХ УЧИТЕЛІВ ІНФОРМАТИКИ ІНТЕЛЕКТУАЛЬНОГО АНАЛІЗУ ДАНИХ: ОБҐРУНТУВАННЯ ВИБОРУ МОВ ПРОГРАМУВАННЯ

\title{
FUTURE COMPUTER SCIENCE TEACHERS TRAINING IN DATA MINING: JUSTIFICATION OF THE CHOICE OF PROGRAMMING LANGUAGES
}

\begin{abstract}
У статті здійснено обгрунтування вибору мов програмування з метою навчання майбутніх вчителів інсрорматики інтелектуального аналізу даних. Це питання вивчено недостатньо та залишається актуальним у зв'язку зі швидким розвитком цифрових технологій. Застосування інтелектуального аналізу даних в освіті оптимізує можливості студентів, викладачів, адміністраціі закладів освіти у здійсненні аналізу освітніх даних, визначенні стану освіти, прийнятті рішень щодо використання педагогічних технологій, управління закладами освіти, проектної діяльності й ін. Для досягнення мети дослідження: проаналізовано праці науковців, зміст навчальних програм Міністерства освіти і науки України, освітніх програм спеціальності Середня освіта (Інорорматика), навчальних програм дисципліни «/нтелектуальний аналіз даних»; проаналізовано рейтинг мов програмування на ринку цифрових технологій і визначено найбільш популярні у цій сфрері мови програмування; охарактеризовано мови програмування з погляду їх використання для навчання майбутніх вчителів інформатики інтелектуального аналізу даних, оскільки їх вибір є необхідною складовою частиною забезпечення есрективності та якості розв'язуваних задач; проведено анкетування викладачів педагогічних закладів вищої освіти щодо пріоритетності вибору мов програмування для навчання інтелектуального аналізу даних майбутніх вчителів інсрорматики.

З'ясовано, що сьогодні існує значна кількість мов програмування для забезпечення інте лектуального аналізу даних. Можливості ї використання визначаються з огляду на їхні характеристики й особливості застосування. Важливими аргументами щодо вибору мов програмування для забезпечення інтелектуального аналізу даних $є$ складність їх вивчення, потужність, ефективність, гнучкість, продуктивність, попит на ринку циярових технологій, можливість використання в навчальному процесі.
\end{abstract}

Ключові слова: вчитель інформатики, вища освіта, педагогіка, інтелектуальний аналіз даних, мова програмування.

The article substantiates the choice of programming languages for the purpose of future computer science teachers train in data mining. This issue has not been sufficiently studied and remains relevant due to the rapid development of digital technologies. The use of data mining in education optimizes the ability of students, teachers, administration of educational institutions in the analysis of educational data, determining the state of education, decision-making on the use of pedagogical technologies, management of educational institutions, project activities and others. To achieve the goal of the research: the works of scientists, the content of educational programs of the Ministry of Education and Science of Ukraine, educational programs of the specialty Secondary Education (Informatics), educational programs of the discipline "Data Mining" are analyzed; the rating of programming languages on the digital technology market is analyzed and the most popular programming languages in this field are identified; programming languages are characterized in terms of their use to future computer science teachers train in data mining, as their choice is a necessary component to ensure the efficiency and quality of tasks; a survey of teachers of pedagogical institutions of higher education on the priority of choosing programming languages for future computer science teachers train in data mining.

It has been found that there are a significant number of programming languages available today to provide data mining. Possibilities of their use are determined taking into account their characteristics and features of application for this purpose. Important arguments for the choice of programming languages to provide data mining are the complexity of their study, power, efficiency, flexibility, productivity, demand in the digital technology market, the possibility of use in the educational process.

Key words: computer science teacher, higher education, pedagogy, data mining, programming language.
Постановка проблеми у загальному вигляді. Процес підготовки майбутніх вчителів інформатики, їхня професійна діяльність ґрунтуються на комплексних рішеннях, в основу прийняття яких покладено вектори розвитку суспільства, гуманістично орієнтовані світові теорії, а також ціннісне осмислення педагогічних практик, наукових досягнень [1, с. 259-265]. У цьому аспекті значимими $€$ суспільне замовлення на підготовку фрахівців, цифровізація освіти, врахування особливих умов функціонування та розвитку освітнього середовища, з яким буде пов'язана профресійна діяльність [2, с. 30-45; 3, с. 30-34] (розв'язання складних задач і проблем у сферах навчання інфрорматики, проведення досліджень, здійснення інновацій). Вирішення цих задач пов'язане 3 аналізом статистичних даних на основі сучасних технологій, що є можливим завдяки інтелектуальному аналізу даних (ІАД) [3, с. 30-34]. Тому набуття студентами компетентностей у сорері ІАД, зокрема оптимального вибору мов програмування для здійснення ІАД, є необхідною складовою частиною їхньої майбутньої профессійної діяльності.

Аналіз останніх досліджень і публікацій. В Україні сфрормовано потужну наукову школу підготовки майбутніх вчителів інформатики з основ алгоритмізації та програмування. Цю проблему досліджували В.Ю. Биков, Р.С. Гуревич, М.І. Жал- 
дак, Н.В. Морзе, Ю.С. Рамський, С.О. Семеріков, В.В. Осадчий й ін. На різних етапах розвитку інформатичної освіти майбутнім вчителям інфрорматики пропонувалися до вивчення мови програмування: ASM, Fortran, Basic, C, Pascal, C++, C\#, Java, JavaScript, PHP, Python, SQL й ін.

У викладанні інфрорматики в закладах загальної середньої освіти (33СО) згідно із програмами Міністерства освіти і науки України, розробленими на їх основі підручниками [4; 5] учням пропонують до вивчення декілька мов програмування, переважно Python i Free Pascal. Проте на основі бесід та опитувань вчителів інфрорматики $33 \mathrm{CO}$ 3'ясовано, що вони, окрім мов Pascal i Python, навчають учнів мов програмування Basic, C++, C\#, Java, JavaScript, PHP.

Закордонними дослідниками V. Amaral, B. Norberto та ін. для вирішення задач ІАД були визначені мови програмування загального призначення C/C++, Python/R, Java й ін. [6].

S. Anitha Elavarasi та J. Jayanthi розглянули питання реалізації алгоритмів машинного навчання у процесі здійснення ІАД із погляду вибору мови програмування [7, с. 402-421]: ними визначено найбільш популярні мови програмування, що використовуються для розробки програм машинного навчання - це Python (57\%), R (31\%) i Java (17\%).

Виділення не вирішених раніше частин загальної проблеми. Питання вибору мов програмування для навчання майбутніх вчителів інфрорматики ІАД вивчено не достатньо та залишається актуальним у зв'язку зі швидким розвитком цифррових технологій. Однією з проблем його вирішення $€$ необхідність поєднання досвіду у сорері ІАД і нових досягнень наукової думки.

Мета дослідження полягає в обґрунтуванні вибору мов програмування для навчання майбутніх вчителів інформатики інтелектуального аналізу даних.

Виклад основного матеріалу. Інтелектуальний аналіз даних (англ. Data Mining; видобування даних, глибинний аналіз даних) використовується для забезпечення процесу «виявлення в даних, невідомих раніше, нетривіальних, практично корисних і доступних інтерпретації знань, необхідних для прийняття рішень у різних сорерах людської діяльності» [8, с. 3-4]. Основою виникнення та розвитку ІАД $€$ такі науки, як штучний інтелект, розпізнавання образів, теорія ймовірностей, статистика, логіка, методи оптимізації, реляційна алгебра, теорія прийняття рішень, теорія управління й ін. Зміст дисципліни «Інтелектуальний аналіз даних» формується з урахуванням потреби у вивченні методів цих дисциплін: класифрікації, асоціації, візуалізації, кластерного аналізу, оптимізації, прогнозування, аналізу ієрархій, нечіткої логіки й ін.
Для досягнення мети дослідження нами був проаналізований зміст актуальних освітніх програм підготовки бакалаврів і магістрів спеціальності Середня освіта (Інформатика) та програм навчальних дисциплін у педагогічних закладах вищої освіти (ЗВО) України.

Аналіз освітніх програм підготовки бакалаврів і магістрів спеціальності Середня освіта (Інформатика) в педагогічних ЗВО України показав, що дисципліну «Інтелектуальний аналіз даних» пропонують до вивчення студентам як бакалаврату, так і магістратури. Метою вивчення курсу є фрормування компетентностей здобувачів у сорері фундаментальних методів інтелектуального аналізу даних, використання їх у професійній діяльності. Попередніми вимогами до вивчення цієї дисципліни $€$ наявність зарахованих кредитів із математичного аналізу, лінійної алгебри й аналітичної геометрії, теорії ймовірностей і математичної статистики, алгоритмізації та програмування, проектування баз даних. Аналіз змісту програм навчальної дисципліни «Інтелектуальний аналіз даних» показав, що у цьому курсі вивчаються методи видобування даних, розробки моделей даних, методи баз даних, статистики, машинного навчання, пошуку даних тощо. Основними задачами цієї сфери є: видобування даних, класифікація, асоціація, кластерний аналіз, оптимізація, прогнозування, аналіз ієрархій, регресія, візуалізація й ін. Для вирішення задач ІАД у переважній більшості розглянутих навчальних програм використовуються бібліотеки алгоритмів, програми, пакети програм, онлайн-сервіси, в яких не передбачається обов'язкове написання програмного коду або фррагментів коду, наприклад: Excel, Weka, SPSS, SAS, STATGRAPHICS, Statistica, Mathcad й ін.; безкоштовні онлайн-сервіси GNU Octave, Graph Online, Maxima, Mas, SMath Studio Cloud, SMath Studio, Scilab й ін. В окремих навчальнихпрограмах використовуються мови програмування, зокрема Python, Java, Matlab, R, C\#, C++, SQL й ін.

Одним із етапів дослідження було проведення бесід, інтерв'ю й анкетування викладачів педагогічних ЗВО України з питань використання мов програмування у навчанні студентів ІАД (рис. 1). В онлайн-анкетуванні із використанням Google Forms брали участь 53 викладачі педагогічних ЗВО різних регіонів України. Ними було названо багато причин вибору тієї чи іншої мови програмування, особливо в дослідженнях з ІАД. У процесі анкетування вони вказали такі важливі характеристики мов програмування з погляду навчання майбутніх вчителів інформатики ІАД: об'єктноорієнтованість, динамічність, легкість вивчення та застосування, наявність потужних можливостей обробки даних, гнучкий синтаксис, вбудовуваність, розширюваність, наявність широкого набору бібліотек, забезпечення підтримки паралельних 
обчислень, наявність додатків для різних сорер досліджень, таких як інтелектуальний аналіз даних, обробка зображень, універсальність тощо.

Результати анкетування викладачів педагогічних ЗВО щодо пріоритетності вибору мов програмування для навчання майбутніх вчителів інорорматики ІАД представлені на рис. 1. Відповідно до отриманих результатів викладачі переважно обирають Python (22\%), C\# (17\%), C++ (15\%). Дещо меншою популярністю користуються JavaScript (10\%) і Java (10\%). Найменше використовуються в навчальному процесі мови R (6\%) і C (5\%). Мову Scala опитані респонденти не використовували.

На основі результатів інтерв'ю та бесід із викладачами педагогічних $3 \mathrm{BO}$ з'ясовано, що така ситуація може бути зумовлена різними причинами, зокрема: відповідністю змісту шкільних підручників; відносною простотою вивчення, труднощами, які можуть виникати в учнів у процесі вивчення алгоритмізації та програмування; небажанням вносити зміни у вже підготовлені навчальнометодичні комплекси дисциплін; небажанням відстежувати тенденції зміни попиту на мови програмування на ринку цифррових технологій й ін.

Розглянемо найбільш популярні мови програмування, котрі можуть бути використані для навчання майбутніх вчителів інфрорматики ІАД. Основними критеріями їх вибору $€$ складність вивчення, потужність, ефективність, гнучкість, продуктивність, попит на ринку цифрових технологій, можливість використання в навчальному процесі.

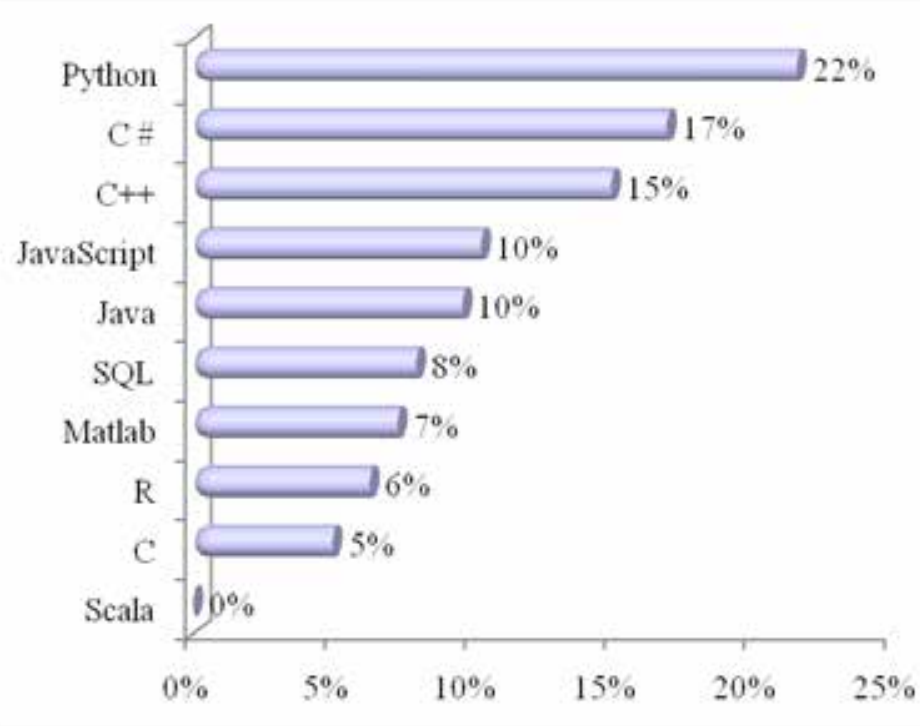

Рис. 1. Результати анкетування викладачів щодо пріоритетності вибору мов програмування для навчання ІАД майбутніх учителів інформатики

$\mathrm{R}$ - потужна ефективна мова для ІАД, має широкий спектр додатків для збору, статистичної обробки та візуалізації даних; ліцензія на використання безкоштовна; має низьку продуктивність.

Python - широко використовується розробниками для ІАД, мова загального призначення, має значну кількість бібліотек, проста у вивченні; ліцензія безкоштовна; можуть виникати помилки типізації.

SQL - ефективний при роботі із запитами, реляційними базами даних, використовується у багатьох додатках, легкий для сприйняття; є платні та безкоштовні версії; більш придатний для обробки даних, ніж для аналітики.

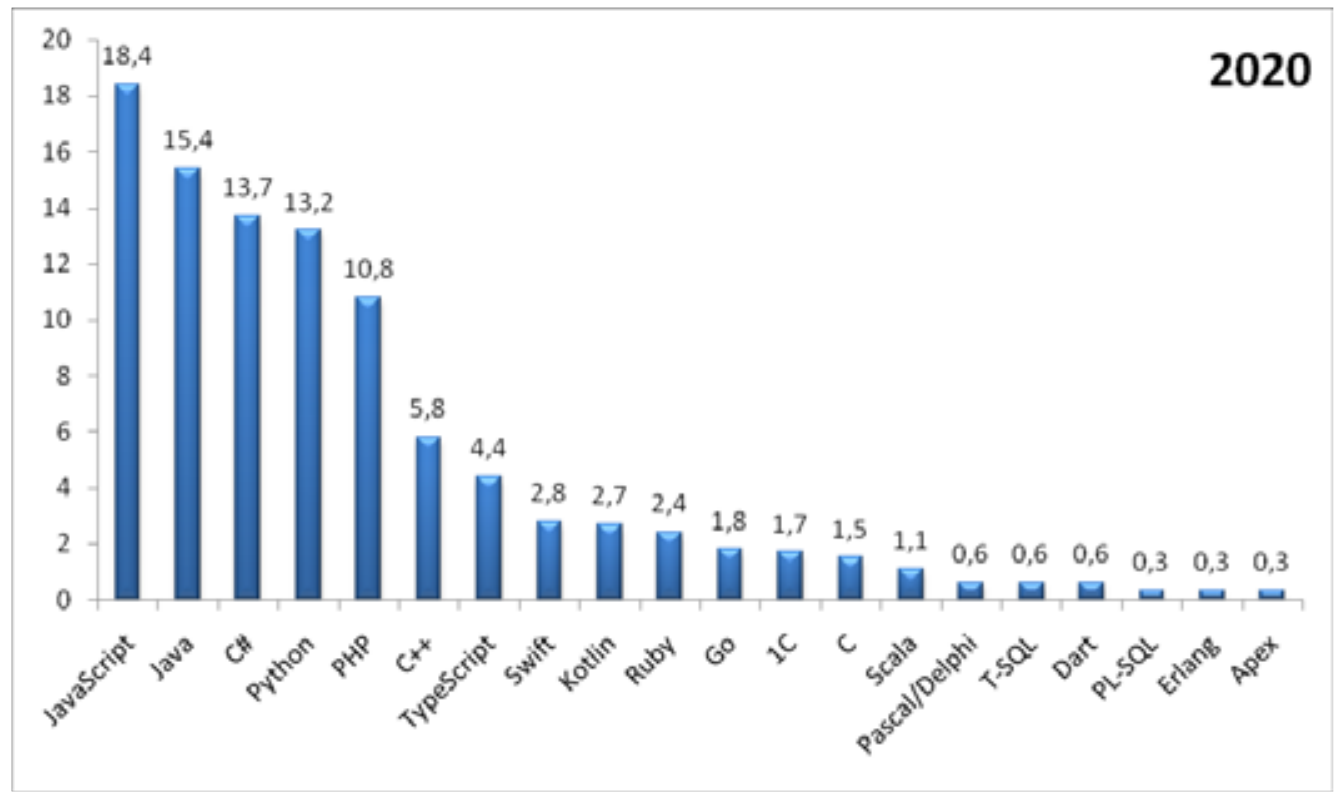

Рис. 2. Рейтинг мов програмування на ринку цифрових технологій 2020 р. [10] 
Java - популярна мова загального призначення, універсальна, має сильну типізацію, високопродуктивна; $€$ безкоштовні версії; складна у використанні з метою спеціалізованого аналізу та статистичної обробки даних, невеликий спектр бібліотек статистичної обробки даних.

Scala - найбільш ефрективна для роботи 3 великими даними у поєднанні зі Spark, peалізовано поєднання об'єктно-орієнтованих і фрункціональних підходів; ліцензія безкоштовна; відносна складність вивчення за рахунок специфіки синтаксису та системи типів.

Matlab - широко використовується 3 метою чисельних обчислень, кількісного аналізу, має ряд можливостей візуалізації даних; платна ліцензія; не найкраща для загального призначення.

Розглянемо рейтинг мов програмування, опублікований P. Шевченко на порталі DOU [9]. Анкетування респондентів було зроблене на початку 2020 р., у ньому взяли участь 9747 фахівців сорери цифрових технологій, 90\% опитаних мешкають в Україні (рис. 2) [9]. Як видно з рис. 2, шість найбільш популярних сьогодні мов програмування JavaScript, Java, C\#, Python, PHP, C++.

Висновки. Таким чином, з урахуванням змісту навчальних програм Міністерства освіти і науки України, освітніх програм спеціальності Середня освіта (Інфрорматика), навчальних програм дисципліни «нтелектуальний аналіз даних», думки викладачів педагогічних 3ВО, характеристик мов програмування з погляду використання для ІАД, рейтингу мов програмування у сорері цифрових технологій для навчання майбутніх вчителів інформатики ІАД найбільш пріоритетними мовами програмування є: Python, Java, C\#, C++, JavaScript. 3 огляду на потужність, ефективність, гнучкість, продуктивність мов програмування для ІАД можна виділити мови Python i Java. Проте остаточний вибір мови / мов програмування для навчання майбутніх вчителів інформатики ІАД і використання з метою розв'язування задач у сорері ІАД повинен залежати від специфіки конкретної освітньої задачі.

\section{БІБЛІОГРАФІЧНИЙ СПИСОК:}

1. Клочко О.В. Теоретичні і методичні засади профресійної підготовки майбутніх менеджерів аграрного виробництва засобами сучасних інформаційнокомунікаційних технологій : дис. ... докт. пед. наук : 13.00.04. Вінниця, 2018. 689 с.

2. Биков В.Ю. Суспільство знань і освіта 4.0. Освіта для майбутнього у світлі викликів XXI cmолimmя, Widawnictwo Uniwersytetu Kazimierza Wielkiego, Bydgoszcz, Republic of Poland, 2017. C. 30-45.

3. Клочко О.В. Інтелектуальний аналіз даних як важлива складова системи професійної підготовки вчителя інформатики. Scientific and pedagogic internship "Pedagogical and psychological edu Somponent of the education system in Ukraine and EU countries". Wloclawek, Republic of Poland, 2019. C. 30-34.

4. Міністерство освіти і науки України. Навчальні програми для 10-11 класів. Iнформатика. 2019. URL: https://mon.gov.ua/ua/osvita/zagalna-serednya-osvita/ navchalni-programi/navchalni-programi-dlya-10-11klasiv (дата звернення: 15.06.2020).

5. Морзе Н.В., Барна О.В., Вембер В.П. Інформатика : підручник. Київ : УОВЦ «Оріон», 2017. 222 с.

6. Amaral V., Norberto B., Goulão M., Aldinucci M. et al. Programming languages for data-Intensive HPC applications: A systematic mapping study. Parallel Computing. 2020. Vol. 91. doi: 10.1016/j.parco.2019.102584.

7. Anitha Elavarasi S., Jayanthi J. Programming Language Support for Implementing Machine Learning Algorithms. Handbook of Research on Applications and Implementations of Machine Learning Techniques, IGI Global. 2020. P. 402-421. doi:10.4018/978-15225-9902-9.ch021.

8. Марченко О.О., Россада Т.В. Актуальні проблеми Data Mining : навчальний посібник. Київ : Київський нац. ун-т імені Тараса Шевченка, 2017. 150 с.

9. Шевченко Р. Рейтинг мов програмування 2020: JavaScript випередив Java, a Dart увійшов у першу лігу. URL: https://dou.ua/lenta/articles/language-ratingjan-2020/ (дата звернення: 15.06.2020). 